\title{
Juvenile polyposis syndrome
}

INSERM

\section{Source}

INSERM. (1999). Orphanet: an online rare disease and orphan drug data base. Juvenile polyposis syndrome. ORPHA:2929

Juvenile gastrointestinal polyposis (IIP) is a rare condition characterized by the presence

of juvenile hamartomatous polyps in the gastrointestinal (Gl) tract. 